\title{
Dissemination of Prevention of the Spread of COVID-19 through the 7 Slum Indicators Approach in Cirebon City
}

\author{
Heni Fa'riatul Aeni, Herlinawati, Lilis Banowati, Suzana Indragiri \\ Cirebon College of Health Sciences \\ henifariatulaeni80@gmail.com
}

\begin{abstract}
Slum areas are known to be incubators of disease because they are occupied by high density residents. This activity aims to conduct dissemination in slum settlements in 11 urban villages (Kesenden, Kebonbaru, Pegambiran, Jagasatru, Pulasaren, Drajat, Sunyaragi, Karyamulya, Argasunya, Harjamukti, and Kecapi) with the theme of Prevention of the spread of COVID-19 through the 7 slum indicators approach. The methods applied in this activity were lecture along with question and answer. This activity was implemented by carrying out health protocols to prevent the transmission of COVID-19 wherein there were only 30 participants attended in each village who were required to wear masks and keep social distancing. This dissemination activity was limited to only 2 hours, effective from 08.30 to 11.00 a.m. Based on the results of the activity implementation, basically most of the people had a fairly good knowledge on COVID-19, but not all had a good attitude since there were some people who thought that the virus mostly attacks the middle to upper class. There was also indifference attitude towards government recommendations since they thought that God determines their health status.
\end{abstract}

Keywords: dissemination, prevention of the spread of COVID-19

\section{INTRODUCTION}

Settlements are part of a residential environment that consist of more than one housing unit which has infrastructure, facilities, public utilities, and has other supporting activities in urban or rural areas. (About Housing and Settlements Area, 2011)

Slum settlements are a problem faced by almost all major cities in Indonesia. According to the Minister of Public Works and Housing No. 02/PRT/M/2016 concerning Quality Improvement of Slum Housing and Settlements (enclosure 2) there are 7 indicators of slum, namely: (1) building criteria; (2) environmental roads; (3) supply of clean and drinking water; (4) environmental drainage; (5) wastewater management; (6) solid waste management; and (7) fire protection. (Wihadanto et al., 2017)

Study on slum settlements generally includes three aspects, namely, first, the physical conditions. These physical conditions, among others, can be observed from the very tight buildings or vey close to each other with low construction quality, the road network which has no pattern and unpaved, public sanitation and drainage which are not functioning and garbage has not been properly managed. The second aspect is the socio-economic and cultural conditions of the communities living in the settlement. The socio-economic conditions of people living in slum areas include low income levels, loose social norms, a culture of poverty that characterizes their lives, which can be seen from their apathy attitude and behavior. The third aspect is the impact of these two conditions. These two conditions often result in poor health conditions, sources of pollution, sources of disease spread and deviant behavior, which in turn may have an impact on their overall life (Handryant, 2012)

Slum areas are known to be incubators of disease because they are occupied by high density residents. Due to a poor quality of houses, as well as limited basic infrastructure and sanitation, slum settlements have various risks that can access the acceleration of the spread of infection. Recently, the COVID-19 pandemic that is spread through breath, talking, coughing and sneezing (WHO, 2020) is an additional challenge for slum settlements which tend to have narrow space for movement. Slum settlements are the object of the threat of the spread of COVID-19 (Anonimous, n.d.). 
Management of slum problems is currently a government program under the Ministry of Public Works and Housing (PUPR) such as the Kotaku (City Without Slum) program. However, it also needs support and coordination from related agencies, including the Public Housing and Settlement Service.

Cirebon City is one of the cities in West Java which has 5 sub-districts and 22 subdistricts. There are 11 urban villages that are included in the slum category, namely, Panjunan, Kebonbaru, Kesenden, Pegambiran, Pulasaren, Kasepuhan, Lemahwutut, Pekalangan, Jagasatru, Pekalipan and Argasunya. The existence of slum villages is part of the duties of the Public Housing and Settlement Service (DPRKP). This Agency has carried out many activities to reduce slums, one of which is to conduct dissemination on slum settlements.

Coinciding with the COVID-19 Pandemic situation and the increasing number of positive cases of COVID-19, the DPRKP conducted a dissemination activity on slum areas with the theme of "Prevention of the spread of COVID-19 through the 7 slum indicators approach".

\section{Materials And Methods}

The dissemination activity for preventing the spread of covid-19 through the 7 slum indicators approach was carried out in 11 urban villages in Cirebon City from 22 July to 27 October 2020. The location of this dissemination activity started from the Kesenden urban village and finally in the Kecapi urban village. The material presented was related to slum settlements and prevention of the spread of COVID-19 through 7 slum indicators approach. The implementation of dissemination activity to prevent the spread of COVID-19 using the 7 slum indicators approach was carried out using the lecture method along with question and answer (discussion). Coinciding with the Covid 19 pandemic and the call for Adaptation of New Habits, this activity was carried out by implementing health protocols to prevent the occurrence of COVID-19 transmission wherein there were only 30 participants attended in each village who were required to wear masks and keep social distancing. This dissemination activity was limited to only 2 hours, effective from 08.30 to 11.00 a.m.

\section{Results And Discussion}

This community service activity was implemented in the form of dissemination in 11 villages (Kesenden, Kebonbaru, Pegambiran, Jagasatru, Pulasaren, Drajat, Sunyaragi, Karyamulya, Argasunya, Harjamukti, and Kecapi) smoothly. Participants were the parties from Community Association, Cadres, Babinsa (village guidance agency), BhabinKamtibmas (The guardian of community security and order), Kotaku Team, and DKM (Mosque Prosperity Council). The evaluation results showed quite high enthusiasm from the participants because the discussion was active and the participants understood the material presented.

The welcoming material delivered by the Public Housing and Settlement Service (DPRKP) regarding slum settlement areas was part of the topics discussed aside from preventing the spread of COVID-19. When the discussion about preventing the spread of COVID-19 through the 7 slum settlement indicators approach was opened, many respondents described problems regarding settlements and among 11 urban villages most (>50\%) of them described problems regarding waste management, water channels, and population density so that house buildings in densely populated areas could not meet standards due to lack of lighting and air circulation. Lack of public awareness regarding waste management and the available infrastructure could not meet the requirements, so there was often a pile of garbage at the landfills. And this may cause flooding when the rainy season arrives. Moreover, there are still many other impacts such as being a source of disease vectors and disturbed aesthetics in the form of unpleasant odors and view. 


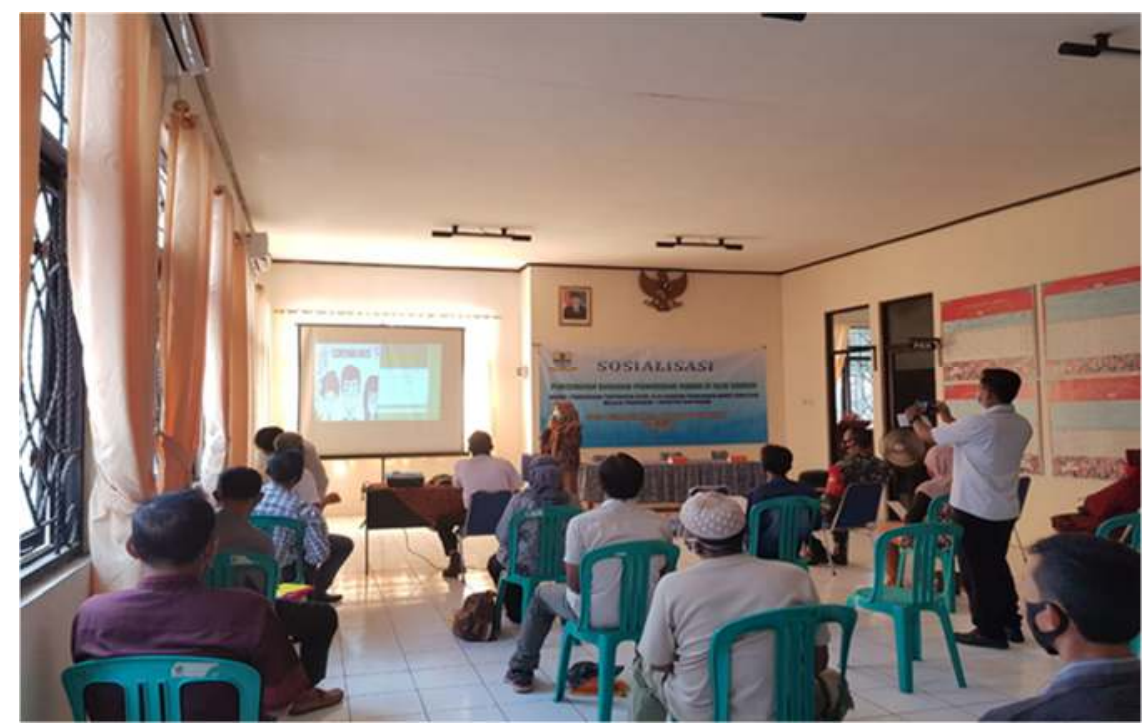

Figure 1. Material Delivery Process in Pulasaren

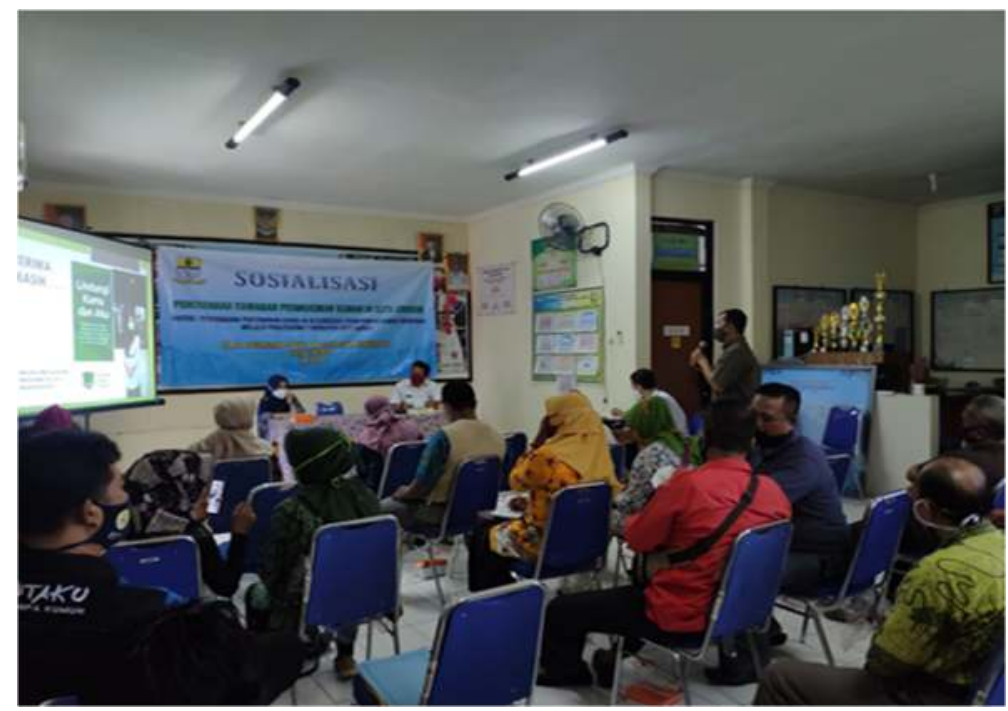

Figure 2. Discussion Process in Karyamulya

Cases of the spread of COVID-19 are increasing over time, but people are increasingly ignoring efforts to prevent COVID-19 transmission. The Ministry of Health socializes ways to prevent and avoid the transmission of COVID-19 virus, namely by implementing 1) washing hands with soap and running water, 2) using masks 3) maintaining social distancing (Ministry of Health of the Republic of Indonesia, 2020).

The Governor of West Java issued Governor Regulation number 60 of 2020 concerning the imposition of administrative sanctions for health order violations in the implementation of large-scale social restrictions and the adaptation of new habits in the response to coronavirus disease 2019 (COVID-19) in the West Java Province. One of explanations delivered by the Governor of West Java is violations for not wearing mask which will be imposed for sanctions in the form of verbal warning, written warning, guarantee of identity cards or social work and administrative fines of IDR 100,000 - to IDR 150,000. (West Java Governor Regulation No.60 of 2020 concerning Imposition of Administrative Sanctions for Health Order Violations in the Implementation of Large-Scale Social Restrictions and Adaptation of New Habits in the Response to COVID-19, n.d.) However, the issuance of this regulation has not raised awareness of the community to implement government recommendations.

Basically, most of the people had a fairly good knowledge on COVID-19, but not all had a good attitude since there were some people who thought that the virus mostly attacks the 
middle to upper class. There was also indifference attitude towards government recommendations since they thought that God determines their health status.

Regarding community behavior in preventing the spread of Covid-19, the $3 \mathrm{M}$ movement was revealed to be carried out only by a small part of the community, such as washing hands when they felt that their hands were dirty, maintaining distance was also difficult to apply because the community recognized that humans could not just stay at home and there were still many activities that needed to be done to make a living/work. In practice, many people only wore masks occasionally, especially when there was a raid, and in fact the masks were actually taken off while speaking.

According to Azwar, behavior is a form of response or reaction to stimuli or stimuli from outside the organism (people), but the response is really depends on the characteristics or other factors of the person concerned (Azwar S, 2011). These factors can come from internal, for example, age, gender, knowledge, education and others, while external factors can come from family support, community leaders, health workers, regulations, facilities and infrastructure. These factors can determine a person's behavior.

Slum areas are known to be incubators of disease because they are occupied by high density residents. Due to a poor quality of houses, as well as limited basic infrastructure and sanitation, slum settlements have various risks that can access the acceleration of the spread of infection. Recently, the COVID-19 pandemic that is spread through breath, talking, coughing and sneezing (WHO, 2020) is an additional challenge for slum settlements which tend to have narrow space for movement (Perkim-id, n.d.).

In various parts of the world, slum settlements are the object of the threat of the spread of COVID-19. In Brazil, for example, it becomes the global center of COVID-19, many favela (slum area) inhabitants have difficulty accessing clean water and cannot afford soap which actually is highly needed to combat the spread of the COVID-19 pandemic. Meanwhile in Lagos, Nigeria's largest city, many informal workers in slum areas have lost their income. Therefore, the government's recommendation to stay at home is difficult for people living in slum areas, because the demands to earn money to survive are much greater. (Perkim-id, n.d.)

In the slum areas, the fact revealed that there was still one house occupied by more than 1 family. In addition, only one public toilet that was used by many residents of the house. The deteriorating economic condition also inevitably encouraged people in the area to keep going out of their residence and looked for a living.

There was also indifference attitude towards government recommendations since they thought that God determines their health status. This requires dissemination effort regarding the understanding of the incidence of illness by religious and public leaders.

Religion has provided important lessons in dealing with epidemics. Staying at home as instructed by the government to cope with the outbreak of OVID-19, is in no way contradicting the teachings of the Prophet. Even as long as COVID-19 rate is still high, the Prophet advises to stay at home with patience, try to avoid it, and when a person was infected by the virus until he dies, such condition is included in dying by martyrdom. In other words, preventive action against the spread of COVID-19 as described in the Prophet's hadith is closely related, synergistic, correlated, and has strong relevance to what the government echoes regarding the recommendation to stay at home (Zulfikar, 2020).

In the management of the spread of COVID-19, social distancing effort is divided into two. The first is self-quarantine for people who have been in contact with a person with COVID-19, but the symptoms have not been identified. People included in these criteria must be quarantined by remaining at home for at least 14 days. The second type is self-isolation for people who were confirmed positive for COVID-19. This is an intensive management effort for people with COVID-19 to isolate themselves in a special room, they are not allowed to leave the room so as not to transmit the virus to other people (Buana, 2017).

Further effort is to maintain the body's immunity. Basically, the human body has an immune system to fight viruses and bacteria that cause disease. However, there are several things that may weaken the immune system, including aging, malnutrition, many diseases, and 
many more. Therefore, the function of the immune system needs to be maintained so that the body's immune system remains strong. Maintaining body immunity is one of the preventive measures against the spread of COVID-19, as well as protecting the body from various other diseases. Consuming nutritional food and drinks is one of the natural ways to maintain and strengthen the body's immunity.

Efforts to prevent the spread of the COVID-19 virus actually require a participatory approach by considering various aspects holistically ranging from social, cultural, health, to economic. The recommendation to stay at home is certainly difficult for people in slum areas who are still looking for income from day to day just to fulfill their food needs. Therefore, any social action taken to deal with the impact of the COVID-19 pandemic requires adequate economic support, especially in the most vulnerable spaces such as slum areas. In this case, development economists recommend direct cash assistance, especially for the poor, as this is a step taken by developed countries. In addition, assistance for the poor to access water, food and sanitation must also be prioritized because these three things are the most essential basic needs in facing the current COVID-19 pandemic. In retrospect, the recommendation to stay at home is a luxury that cannot be enjoyed by all levels of society. Therefore, cooperation between all parties, including the government, private sector, organizations, and the community is also highly needed as social capital to create resilient communities towards COVID-19 pandemic, especially in vulnerable slum areas.

\section{CONCLUSIONS AND RECOMMENDATIONS}

Communication, information and education are important things that must be implemented through dissemination, counseling and training on preventing the spread of COVID-19 in order to increase knowledge, attitudes and behavior of the community. There is an importance of supervision and enforcement of strict sanctions against violations of rules that have been made in accordance with the provisions.

\section{ACKNOWLEDGEMENT}

This community service activity can be implemented well because of the participation of many parties. Therefore, we would like to express our deepest gratitude to: 1) Public Housing and Settlement Service (DPRKP) which has trusted us as resource persons, 2) Kesenden, Kebonbaru, Pegambiran, Jagasatru, Pulasaren, Drajat, Sunyaragi, Karyamulya, Argasunya, Harjamukti, and Kecapi Urban Villages which have provided places for this dissemination activity, 3) All participants/invitees who have attended this activity.

\section{REFERENCES}

Anonim. (n.d.). Pandemi Covid-19 dan ancamannya bagi masyarakat pemukiman kumuh. http://www.caritra.org

Azwar S. (2011). Sikap dan Perilaku dalam:Sikap Manusia Teori dan Pengukurannya. Pustaka Pelajar.

Buana, R. D. (2017). Analisis Perilaku Masyarakat Indonesia dalam Menghadapi Pandemi Covid19 dan Kiat Menjaga Kesejahteraan Jiwa. Sosial Dan Budaya, Fakultas Syariah Dan Hukum Universitas Islam Negeri (UIN) Syarif Hidayatullah Jakarta, 53(9), 1689-1699. file:///C:/Users/User/Downloads/fvm939e.pdf

Handryant, A. N. (2012). Permukiman Kumuh, Sebuah Kegagalan Pemenuhan Aspek Permukiman Islami. Journal of Islamic Architecture, 1(3). https://doi.org/10.18860/jia.v1i3.1774

Kementerian Kesehatan RI. (2020). Penerapan 3 M. Kementerian Kesehatan RI. http://www.p2ptm.kemkes.go.id

Peraturan Gurbenur Jawa Barat No.60 Tahun 2020 tentang Pengenaan Sanksi Administratif terhadap Pelanggaran Tertib Kesehatan dalam Pelaksanaan Pembatasan Sosial Berskala Besar dan Adaptasi Kebiasaan Baru dalam Penanggulangan Covid-19. 
Perkim-id. (n.d.). Pandemi Covid-19 dan Ancamannya Bagi Pemukiman Kumuh. Retrieved June 9, 2021, from https://perkim.id/perumahan/pandemi-covid-19-dan-ancamannya-bagipermukiman-kumuh/Tentang Perumahan dan Kawasan Pemukiman, (2011).

Wihadanto, A., Barus, B., Achsani, N. A., \& Bratakusumah, D. S. (2017). Analisis Karakteristik dan Penilaian Tingkat Kekumuhan Kawasan Permukiman 'Kampung Braga' - Kota Bandung. Journal of Regional and Rural Development Planning, 1(2), 132-144. https://doi.org/10.29244/jp2wd.2017.1.2.132-144

Zulfikar, E. (2020). Tindakan Preventif atas Penyebaran Covid-19 dalam Perspektif Hadis. Diroyah : Jurnal Studi Ilmu Hadis, 5(1), 31-44. https://doi.org/10.15575/diroyah.v5i1.8924 